\title{
REVIEW JURNAL PEMBANGUNAN BERKELANJUTAN
}

\section{IRMA TRI ANNISYA TOMBORA}

C1 B117 052

Ilmu Komunikasi Konsentrasi Ilmu Hubungan Internasional Universitas Halu Oleo

\section{Tinjauan Implementasi Pembangunan Bekelanjutan : Pengelolaan}

\section{Sampah Kota Kendari}

Permasalahan yang diangkat dalam membahas jurnal ini yaitu , dengan meningkatnya pertumbuhan populasi penduduk dunia juga urbanisasi yang terjadi menimbulkan permasalahan dalam peningkatan produksi sampah dunia, bukan hanya di dunia secara global hal ini juga terjadi di Kota Kendari. Sehingga dalam penanganan yang dilakukan untuk mengatasi sampah ini sejalan dengan target yang ingin di capai Sustainable Development Goals (SDGs) yang termasuk dalam pointnya yaitu mengurangi dampak yang merugikan lingkungan kota termasuk dalam hal ini menangani sampah di perkotaan.

Dalam mendukung untuk mengatasi masalah tersebut maka penelitian ini bertujuan untuk membahas bagaimana pengelolaan sampah di Kota Kendari, tantangan apa saja yang di hadapi dalam pengimplementasian kebijakan pengelolaan sampah di Kota Kendari, juga bagaimana implementasi kebijakan penglolaan sampah berbasis pembangunan berkelanjutan. Hal tersebut dilakukan dalam upaya untuk mewujudkan visi dan misi Kota Kendari menjadi Kota Layak 
Huni (Liveble City) yaitu dimana terlaksananya pembangunan Kota Kendari yang berkelanjutan dengan mengurangi masalah lingkungan yang mempunyai dampak negative dalam pelaksanaan pembangunan perkotaan.

Dalam jurnal ini menggunakan metode penelitian deskriptif dengan pendekatan kualitatif dengan lokasi penelitian di Kota Kendari. Sumber data yang digunakan yaitu data primer dan data sekunder yang di kumpulkan dengan beberapa metode. Metode yang digunakan yaitu wawancara bersama Kepala Bidang Persampahan Dinas Lingkungan Hidup Dan Kehutanan Kota Kendari , Camat Poasia, dan Lurah Baruga Kota Kendari. Selain itu, Metode analisis data yang digunakan dalam jurnal ini yaitu analisis model interaktif dengan cara pengumpulan data, reduksi data, penyajian data, dan simpulan (Miles \& Huberman, 2007). Focus pada penelitian ini yaitu tantangan implementasi kebijakan pengelolaan sampah ditinjau pada aspek Komunikasi, Sumberdaya, Disposisi, dan Struktur Birokrasi. Sedangkan analisis implementasi kebijakan berbasis Suistainable Development diuraikan pada tiga aspek yaitu, Ekonomi , Sosial, dan Lingkungan.

Hasil dari penelitian ini yaitu Implementasi kebijakan pengelolaan sampah di Kota Kendari masih menghadapi tantangan di masing-masing aspek, pada aspek komunikasi, penyampaian komunikasi seperti instruksi dinas ke petugas mengenai pengelolaan sampah tersampaikan dengan jelas, serta telah ada sosialisasi melalui papan informasi sebagai bentuk komunikasi DLHK Kota Kendari bagi masyarakat. Namun tantangannya adalah rendahnya tingkat pengetahuan masyarakat di mana hanya 37 persen yang pernah mendapatkan informasi/sosialisasi mengenai penyelenggaraan pengelolaan sampah.

Pada aspek sumberdaya telah tersedia sarana prasarana dan SDM yang mampu mengurangi jumlah timbunan sampah yang di bawah ke TPA.Namun tantangan yang dihadapi ialah masih ada daerah atau wilayah yang belum terlayani secara periodik karena keterbatasan armada dan sumberdaya manusia.Sumberdaya manusia berupa petugas pengangkutan sampah milik 
pemerintah (petugas harian lapangan) dinilai masih kurang apabila dibandingkan dengan luasnya wilayah yang harus dijangkau oleh petugas pengangkut.

Pada aspek struktur birokrasi di Dinas Lingkungan Hidup dan Kehutanan Kota Kendari dilaksanakan dengan baik dan benar sesuai dengan SOP dan tanggung jawab pelaksana. Namun, belum ada koordinasi antar instansi untuk pembentukan tim yustisi serta penegakan sanksi denda atau pidana. Namun terlepas dari semua itu implementasi kebijakan pengelolaan sampah telah memperhatikan aspek-aspek pembangunan berkelanjutan yaitu ekonomi di mana keberadaan Bank Sampah tidak hanya mampu mengurangi jumlah timbunan sampah namun juga telah membantu perekonomian masyarakat.

Pada aspek sosial pemahaman, kesadaran, serta partisipasi masyarakat dalam implementasi kebijakan pengelolaan sampah juga cukup baik seperti penyediaan tempat penampungan sampah harian. Dan pada aspek lingkungan keberadaan TPAS telah dikembangkan pada pemanfaatan gas metan sebagai operasional energi listrik. Hal ini pun secara langsung telah mendorong upaya pencapaian SDGs pada tujuan ke 11 dengan indikator $73.30 \%$ persen sampah di Kota Kendari telah tertangani.

Saran yang dapat diberikan dalam review ini yaitu selanjutnya peneliti mungkin dapat melanjutkan penelitian mengenai mengatasi hambatan - hambatan yang terdapat dalam implementasi kebijakan pengelolaan sampah di Kota Kendari dapat teratasi dan mendorong dalam upaya pencapaian SDGs. Bukan hanya mengenai penegelolaan sampah, dalam upaya mencapai SDGs masih banyak sektor lain yang dapat di jadikan dalam sebuah penelitian lebih lanjut.

\section{Peluang dan Tantangan Pengembangan Indrustri Kreatif Kuliner dalam Pencapaian SDGs}

Dengan berkembang dengan pesatnya Industri Kreatif Indonesia membuat perhatian khusus pada sector Ekonomi Kreatif yang berkontribusi secara signifikan pada pertumbuhan ekonomi nasional. Sektor ekonomi kreatif juga 
termasuk dalam upaya pencapaian Tujuan Pembangunan Berkelanjutan 2030 (SDGs) dimana salah satu jenis industri kreatif yang banyak diminati yaitu subsektor kuliner. Hal inilah yang menjadi masalah dalam penelitian ini yaitu Industri kreatif kuliner merupakan hal potensial yang dapat dikembangkan di Kota Kendari dalam pencapaian pembangunan berkelanjutan melalui implementasi SDGs.

Kemudian yang menjadi tujuan dalam penelitian ini yaitu untuk mengetahui kondisi pendukung dan penghambat atau peluang dan tantangan dalam pengembangan industri kreatif kuliner di Kota Kendari serta keselarasannya pada upaya pencapaian SDGs dengan focus pada sub sektor kuliner dalam dua kategori yaitu jasa kuliner (foodservice) dan barang kuliner (Specialty foods).

Metode penelitian yang digunakan yaitu deskriptif kualitatif untuk menganalisa kondisi pendukung dan penghambat sebagaiu peluang dan tantangan pengembangan industri kreatif kuliner di Kota Kendari. Pengumpulan data yang dilakukan dengan wawancara dan dokumentasi para narasumber yaitu Kepala Bidang Pembangunan Sumber Daya Industri, Dinas Tenaga Kerja dan Perindustrian Kota Kendari. Kepala Seksi Pembinaan dan Pengembangan UKM, Dinas Perdagangan, Koperasi dan UMKM. Pelaku usaha industri kreatif kuliner Kota Kendari, dan Ketua Organisasi Triple K (Komunitas Kuliner Kendari).

Hasil dari penelitian ini yaitu Industri kreatif kuliner telah tumbuh dan berkembang cukup pesat di Kota Kendari. Ruang lingkup Industri kreatif kuliner di Kota Kendari dibagi dalam dua yaitu industri jasa kuliner (food service) dan Industri barang (speciality food). Kota Kendari yang merupakan kawasan perkotaan di mana ruang lingkup industri kuliner paling banyak ditemui adalah industri jasa (food service) seperti warung makan, restoran dan cafe. Sementara untuk industri speciality food sebagian besar merupakan industri olahan produksi rumah tangga. Adapun peluang dan tantangan yang mempengaruhi industri kreatif kuliner di Kota Kendari seperti adanya minat kewirausahaan pelaku industri 
kreatif kuliner, kreatifitas pelaku usaha industri kreatif kuliner, kuliner sebagai lifestyle and leisure, serta dukungan program pemerintah dalam pengembangan kuliner.Sementara untuk tantangan yang dihadapi yaitu modal usaha, perizinan, dan tempat/ruang usaha. Namun terlepas dari tantangan tersebut, pertumbuhan industri kreatif kuliner sebagai dunia usaha di Kota Kendari juga turut berkonstribusi dalam upaya pencapaian SDGs pada tujuan ke 8 terkait petumbuhan ekonomi yang berkelanjutan dan inklusif, lapangan kerja penuh dan produktif, serta pekerjaan yang layak untuk semua utamanya pada target 5 dan 6 terciptanya lapangan pekerjaan bagi laki-laki dan perempuan dan menyerap tenaga kerja usia muda.

Saran yang dapat diberikan mengenai jurnal penelitian ini yaitu selanjutnya dapat dikaji lebih lanjut mengenai bagaimana peran pemerintah daerah dalam mengembangkan industri kreatif kuliner yang ada di kota Kendari. Bukan itu saja dapat juga seberapa efektif promosi pertumbuhan ekonomi kreatif di berbagai bidang dapat mendukung SDGs khusunya dalam hal menciptakan lapangan pekerjaan seperti yang ada pada tujuan ke 8 di Kota Kendari menjadi bahan penelitian lebih lanjut.

\section{References}

[1]Sudirman, F. A., \& Phradiansah, P. (2019). Tinjauan Implementasi Pembangunan Berkelanjutan: Pengelolaan Sampah Kota Kendari. JURNAL SOSIAL POLITIK, 5(2), 291-305.

[2]Sudirman, F. A., Susilawaty, F. T., \& Adam, A. F. (2020). Peluang dan Tantangan Pengembangan Industri Kreatif Kuliner dalam Pencapaian SDGs. Societas: Jurnal Ilmu Administrasi dan Sosial, 9(1), 12-24. 